\title{
Surnames in American Wordplay
}

\section{Grant Loomis}

W

ORDPLAY AND PUNNING lie at the basis of a very large segment of American journalistic humor, particularly in the pioneer days before the Civil War. Hackneyed traces persist to our own times in the belabored efforts of professional gag-men, those feeders of jests to the frequently feeble purveyors of wit on radio and television programs. In sturdier days, patterns of double meaning were numerous. Any word, phrase, regional allusion, or name might serve as a stimulation for the creation of a pun within a particular formula, such as the Wellerism, riddle, conundrum, proverb, epigram, definition, and the cliché. ${ }^{1}$ Rough and ready editorial comment likewise ventured to apply a double meaning to given names and to surnames, whenever the opportunity arose. The laws of libel have long since put an end to the invective-elements of such wordplay. In earlier times, the editor risked bodily harm frequently for the sake of a jibe which he could evolve from a name. Such allusions were dated commonly by political situations, as well as by contemporary manners and customs. However, such name-punning can claim no originality as a formula. Examples may be found in all European languages, as well as in antiquity. Only the variations of application suggest specialized American coloration.

A convenient source for illustration of name-punning appears in a rare book, Prenticeana, or Wit and Humor in Paragraphs, New York, 1860. The author and compiler, G. D. Prentice, old-time newspaper man, noted the origin of his selections in his foreword: "It (the book) is made up of a portion of the paragraphs that I have written for the Louisville Journal (Kentucky) during the last twenty-nine years, and a few of those written for the New York Ledger within the last two years." Among the several hundred selections which consist of a few lines to as much as half a page,

1. See my studies in Western Folklore as follows: VIII, 216-236; 243-247; 348-357; IX, 147-152; XIV, 110-113; and 229-245. 
Prentice's propensity for name-play appears frequently. One may assume that his efforts were only a slight representation of a common usage. The illustrations are sufficiently varied, however, to display the possibilities of punning in this vein.

The following arrangement begins with the name which is subject to wordplay, selects, then, the pertinent section of the paragraph which yields the punning-application, and annotates, when necessary, the phraseology of more than a century ago by reference to A Dictionary of Americanisms (edited by Mitford M. Mathews, 2 vols., U. of Chicago Press, Chicago, 1951. Referred to as Mathews).

1. Aker. Mr. Aker... is a wise-aker (p. 109). Wiseacre: in the sense of foolish fellow; one who thinks himself wise. English origin.

2. Bagg. Mr. Bagg... like many other bags, is getting mealy mouthed (p. 176). Mealy mouthed: hypercritical, hairsplitting. English origin.

3. Barry. Probably his voice is a fine Barry-tone (p. 95). Baritone, spelled formerly, Barytone.

4. Bean. Mr. Bean... shelled out (p. 35). Shell out: to pay up or hand over. Mathesws, 1857. Probably earlier.

5. Bender. Mr. Bender hurt Mr. Scott. The latter is not the first damaged by a bender (p. 297). Bender: a drinking spree. Mathesws, 1846. Probably earlier.

6. Belly. Mr. Belly is cramped (p. 243). To be cramped: to be lacking in funds. Not in Mathesws.

7. Bill. Bill Johnson says that Gen. Harrison's private character is not reputable. That's a lie-Bill (p. 44).

J. S. Bill has set up a shaving shop. Whenever he takes off his beard, he shaves a bad Bill (p. 217). Shave: an exorbitant discount on a note. To cheat. Mathesws, 1807.

8. Bower. Mr. G. J. Bower whipped his wife, and she left him. She was the right Bower, and he was the left one (p. 252). Bower: card game, euchre. The right bower (jack) is higher. Mathesws, 1830.

9. Boyle. A pettifogger was chastised by a lawyer named Boyle. He got into hot water and was Boyled (p. 63).

10. Brewer. Mr. and Mrs. Brewer of Wayne Co. have 22 children. Theirs is, perhaps, the most extensive brewery in the West (p. 47).

11. Bucket. Ned Bucket expresses the wish that we were dead. Let him show himself in person and we pledge ourselves to kick 
the Bucket (p. 38). To kick the bucket: to die. Originally, kick meant to die. The phrase is not noted by Mathesws.

12. Bullit. A gentleman killed himself in Florida for the love of a Miss Bullit. The poor fellow could not live with a Bullit in his heart (p. 296).

13. Bush. A couple of robbers fell upon John Bush of Baton Rouge and robbed him of a shin-plaster. That was taking the rag from the Bush (p. 56). Shin-plaster: poor paper money. Mathesps, 1824. To take the rag from the bush: to surpass, excel. Perhaps a target for rifle-shooting. Mathesws, 1810.

14. Buswell. Mary Ann Buswell has been indicted for having three husbands. If her personal accomplishments are in keeping with her name, she can no doubt get as many husbands and lovers as she pleases (p. 252). Buss: kiss. English.

15. Carr. A Mr. Carr of Mississippi declares for Yancy's southern league. Here's a Carr off the track. Fortunately it is an empty one (78).

16. Cherry. Mr. Hall has been indicted for biting off the nose and part of the ear of Samuel Cherry. He was wrong to make two bites of a cherry (p. 31). Old proverb.

17. Clapp. We have fairly caught our neighbor Clapp at last. Wisconsin Democrat. We presume you did it whith Clap-trap (p. 257). Claptrap: tricky or hyperbolic language. English.

18. Cooley. Our advise to Mr. Cooley can be given in a few words. If any political opponent chastise you... take it Cooley (p. 57). Take it cooly: to act calmly, but here, take means: put up with, endure.

19. Crickett. Two cousins, named Crickett, were married last week... We are opposed to such crickett-matches (p. 26).

20. Day. A locofoco postmaster in New Hampshire, named Day, has been charged with malfeasance in office. He has called his clerks as witness. They are expected to lie for him. That is no doubt the order of the Day (p. 161).

Mr. Day of Colchester has brought action against his neighbor for stealing his dog. No doubt he thinks that every dog should have his day, and every Day his dog (p. 37).

21. Ditto. We have received a locofoco paper published by a Mr. H. A. Ditto. We do not say that Ditto is a knave but many of his party are, and he is -- Ditto (p. 78). 
22. Dorr. A Mr. Dorr has declined a challenge in Missouri. He says he will fight under no circumstances. He is no battle-door (p. 35). Battledore: a racket used to strike the shuttlecock in a game. Here: He is not one to strike back.

23. Dutee. Rhode Island has declined to re-elect Dutee J. Pearce to Congress. She has discharged her Dutee (p. 50).

24. Fall. J. S. Fall, a Mississippi editor, asks when we shall get wise. Undoubtedly before Fall if ever (p. 36).

25. Field. A. W. Field suggests that the Whigs run the devil for the next presidency. We rather guess that the devil will take the Field without any agency on the part of the Whigs (p.135).

26. Fitz. The Illinois Democrat boasts that an American named Fitz Hubert has joined the Democracy. We have no objection to giving them Fitz (p. 243). To give some one fits: to scold violently. Mathesws, 1844. Probably earlier.

27. Fox. The Alabama Journal says that Mr. Fox of the House of Representatives is full of fire. Fox-fire, we presume (p. 52). Fox-fire: phosphorescent light emitted by decaying timber, hence, of no danger. Originally English but common in the U.S. only. Mathews, 1853. Probably earlier.

28. Frost-Fry. Miss Frost of Mass., sued a Mr. Fry for a breach of promise of marriage and recovered $\$ 365$ damages. He courted her a year and had to pay a dollar a day! We should say that Miss Frost was pretty thoroughly fried, and Mr. Fry pretty thoroughly frosted (p. 121).

29. Gill. Messrs. E. \& S. A. Gill... announce their abandonment of the Democratic party. There's no chance for the Democracy to escape, now that the Opposition have got hold of their Gills (p. 256). To have hold of the gills: Way of carrying a fish so that it cannot escape.

30. Goe. In one of the strong Jackson counties of North Carolina, the Democrats put Mr. J. Goe upon their ticket. He was a popular man, but the result was no Goe (p. 34). Go: prize fight. Here to be no contention.

31. Goliah. An editor in the West boasts that his enemies will find him a young David. Very few read his paper without feeling disposed to exclaim - Go-liar! (p. 149).

32. Grubb. The English papers speak of the daughter of an old miser named Grubb, who lately married and is exciting quite a 
sensation in the fashionable world. Nothing is more natural than that ceasing to be a Grubb she should become a butterfly (p. 238).

33. Hardy. The editor of the Eastern Mercury says that the Whig party is losing strength. In as much as his name is Hardy, we can't better reply to him than by the old quotation, "There is no fool like the fool-Hardy" (p. 56).

34. Hurry. A quizzical editor in Arkansas, who rejoices in the name of Harry Hurry, says that truth is generally slow in progress. Probably it is never in such a Hurry as he (p. 6).

35. Hood. Mr. William Hood was robbed near Corinth, Alabama. The Corinth paper says that the name of the highwayman is unknown, but there is no doubt that he was Robbin' Hood (p. 27).

36. Hooe. W. H. Hooe, a postmaster in Vermont, publishes that two hundred dollars of the public funds are missing from his office, and asks, "Who has got the money?" Possibly echo may answer Hooe (p. 61).

37. Horn. Mr. A. H. Horn of the Southern Argus makes some unintelligible threats against us. His language sounds belligerent. Is he a powder-Horn? (p. 79).

38. Hunt. So far as the gentleman is concerned he is a vain and unprofitable Hunt (p. 8).

39. Jennie. Mrs. Jennie R., a danseuse, is advertised to whirl fifteen times on one foot without stopping. She is a spinningjenny (p. 166).

40. Bergen. J. O. Berger has been appointed postmaster in Alabama. We hope the government will not find him a bad J. O. B. (p. 74).

41. Keitt. Keitt of South Carolina is soaring aloft before Palmetto audiences on the "Study of Nature." His constituents can't do better than let him fly (p. 220). That is, let him go. See the expression: Go fly your kite! meaning, to be gone.

42. Kenny. In the swamps of Louisiana, a catamount leaped from a tree and attacked Mr. William Kenny. The animal didn't prove to be a Kill-kenny cat (p. 180). Kilkenny cats were two which fought until only their tails remained. English Oxford Dictionary, 1852. Probably earlier.

43. Knott-Shott. A duel was fought in Mississippi by Mr. T. Knott and Mr. A. W. Shott. The result was that Knott was shot and Shott was not (p. 123). 
"Do you think me guilty of a falsehood?" asked Mr. Knott of a gentleman he was addressing. "Sir, I must render a verdict of Knott guilty." (p. 191).

44. Knower. Mr. J. C. Knower of Iowa confesses that he has travelled around at least one-third of the entire political circle. We suppose that the portion of the circle he has travelled around may properly be styled Knower's Arc (Noah's Ark) (p. 114).

45. Lamb. Mrs. A. Pratt of Philadelphia, aged seventy-five, has married a young man named Lamb. One would think that she is old enough to desire peace and quiet instead of having a bed-lamb always about her (p. 240).

46. Land. A Rocky Mountain correspondent of the New York Post who writes himself Henry E. Land, describes Oregon as the most delightful country in the world. Our citizens, if they choose, can go out there and see how the Land lies (p. 129).

47. Longfellow. A rhymer sends us some of his verses and describes himself as six feet four inches high. In spite of his height, he is no Longfellow (p. 28).

48. Love. Mr. John Love of Alabama was recently lost during a passage from Texas to Mexico. We had supposed that no Love would ever be lost between those countries (p. 33). Allusion to the Mexican troubles of 1845 .

49. Luse. Mr. J. P. Luse has succeeded the Messrs. Terrill in the management of the Lafayette (Ind.) Journal. The Democratic papers all slandered the Terrills, and now we suppose they will be lying about Luse (p. 286).

50. Lyon-Lamb. Mr. H. Lyon, in a speech before the New York Legislature, asserted that the Whigs are seeking to ruin the country. Mr. Lamb of the Lansingburgh Gazette indorses the slander. Thus is the prophecy fulfilled. The Lyon and the Lamb shall lie together (p. 38).

51. Mander. We respectfully suggest to Mr. Henry J. Mander and his bride that they name their first boy Gerry, and their first girl Sally (p. 290).

52. Mile. A strong-fisted servant girl was recently assaulted by a couple of scoundrels, named John and Elam Mile, and flogged them both. We have heard that a miss was as good as a mile, but here was a case in which a miss was as good as two Miles, and a little better (p. 113). 
53. Moore. We have received a North Carolina paper, purporting to be edited by James White Ainsley Moore. Instead of J. White A. Moor, he should have been christened J. Black-A. Moor (p. 43).

54. Nat. Nat Loomis of the Southern Argus may abuse us as much as he pleases. We do not war with gnats (p. 52).

55. Obin. A Mr. Henry Obin argues in favor of the immediate destruction of all banks. The Christian name of Obin should have been Jack (p. 255).

56. Orr. Mr. Orr of South Carolina desires to unite the North and the South. Orr is more likely to disjoin them. Or is a disjunctive conjunction (p. 265).

57. Padd. Mr. S. W. Padd advertises that he has lost his horse. We hope he'll not turn foot-pad (p. 37).

58. Parr. James Ray and John Parr have started a locofoco paper in Maine. Parr, in all that pertains to decency, is below zero; and Ray is below Parr (p. 99).

59. Pike. The personal appearance of Pike, the clever migratory editor, speaks of him as bald. We didn't suppose there was much growth upon Pike's Peak (p. 296). Peak, in the sense of the head of a person is not common. Not in Mathesws.

60. Pillow. A friend sends us a letter of Gen. Pillow which he asks us to notice. We have more important matters on hand. When we have disposed of them, we may attend to the Pillow-case (p. 199).

61. Poe. Mr. L. A. Poe has had one Dr. Rivers indicted for kicking him. He calls the Doctor a savage. If the offender really is a savage, he probably belongs to the Kick-a-Poe tribe (p. 260).

62. Polly Troone. Mrs. Polly Troone has been convicted of slandering her neighbors. A good many unconvicted Pol-troons of the other sex are habitually guilty of the same offence (p. 7).

63. P. O. Thomas. The Southern Mercury says that Mr. P. O. Thomas has received his commission as Postmaster. So there's a post-office gone to P. O. T. (p. 64).

64. Pott. We have received a furious letter from Thomas Pott of Mississippi. He threatens our life. There is evidently "death in the Pot." (p. 37).

65. Prince. The Eastern Telegraph boasts that two brothers named Prince have deserted the Whig ranks and joined the Democrats. "Put not your trust in Princes." (p. 33). 
66. Rhule. Mr. Henry A. Rhule says that he has worked zealously for the administration. Now let him turn and work faithfully against it. 'Tis a poor Rhule that won't work both ways' (p. 37).

67. Jack Robinson. John Robinson, the editor of a locofoco paper in Michigan, says that it is very easy to tell who is the most knavish politician in the United States. We admit that it is just as easy to tell, as it is to say, "Jack Robinson." (p. 174). An old saying, still in use. Not in Mathexs.

68. Role. J. H. Role asks whether the silly Whigs will again put their big ball in motion. We rather think the smart ones will. The bawling of the Role will not prevent the rolling of the ball (p. 175).

69. Rubb. Mr. John Rubb publishes in a Mississippi paper that the Whigs are the corruptest party in the world. "There lies the Rubb." (p. 28).

70. Rule. In a recent criminal trial in Texas, a certain Gen. Rule took it in a high dudgeon because he was challenged by the Commonwealth's attorney. The sensitive gentleman ought to have remembered that there are exceptions to all Rules (p. 230).

71. Shaw-Pugh. An Alabama paper calls Mr. -- a Van Buren man, on the alleged authority of a Mr. Shaw of Tennessee and Mr. Pugh of the Lexington Gazette. To Shaw's authority we say pshaw! and to Pugh's, pooh! (p. 6).

72. Shop. Mr. J. W. Shop is a Democratic candidate for the Legislature in Vermont. No doubt the locofocos expect to lift him into office. A good many of them are great at Shop-lifting (p. 90).

73. Smart. Mr. J. Smart of St. Paul was prosecuted by a young widow for breach of promise. He settled the difficulty by marrying her. He made her Smart lest she should him (p. 288).

74. Sparks-Flint. Two men, Joseph Sparks and Oscar Flint were assailed in the suburbs of Baltimore by a gang of shoulder-hitters. Flint was knocked down, but his companion escaped by flight. When the scoundrels hit Flint, Sparks flew (p. 223).

75. Spoon-Plate. The Upper Canada Standard records the seduction and abduction of Miss Eloisa Spoon by Henry Plate. Old marvels are enacted anew. "The dish ran away with the Spoon." (p. 30).

76. Starr. A Mr. Starr of Georgia shot a Cherokee Indian the other day in the gold region. He is a shooting-Starr (p. 10). 
77. Stone. Mr. James Stone of Mississippi denounces his own party for disfranchising that State. The Locofoco outrages make the very Stones cry out (p. 62).

A locofoco paper in New York professes to have cornered Col. Stone of the Nesw York Commercial. We suppose the colonel has no objection to being considered a "corner-Stone". (p. 109).

78. String. Mr. Amaziah String advertises in the Georgia Constitutionalist that a young man has run off with his two daughters. That is outrageous. What's the use of two Strings to one beau? (p. 27).

79. Sute. The Pennsylvania Democrat acknowledges that Mr. M. R. Sute, a Democrat, will vote for Taylor. A good many other Democrats will follow Sute (p. 156).

80. Terry. All the locofoco papers in Alabama threaten the people of the State with terrible things if Terry should be beaten. The results show that the people were not to be Terry-fied (p. 125).

81. Treat. Mr. Treat is the principal editor of the St. Louis Union, although he does not venture to avow himself as such. The reason is that he is unpopular with the St. Louis locofocos, because he has been temperate in his locofocoism. We do not think that their own political intemperance is any good reason why they shouldn't stand Treat (p. 139).

82. Webb. A locofoco editor in Illinois was kicked the other day by Mr. Henry Webb. The fellow escaped by jumping into the Mississippi. We suppose that, finding himself web-footed, he thought the river his natural element(p. 133).

83. Webster. The Georgia Constitutionalist says that Mr. Wright is fully the equal of Mr. Webster in tearing from a question the web of sophistry. Indeed he isn't; he is very acute, but he can never make a web stir (p. 64).

84. Woods. A fellow named Woods is writing in an Indiana paper very intemperately in favor of cold water. We guess very little cold water ever passes that neck of the Woods (p. 291). Neck of the woods: backwoods expression for an out-of-the-way place. Mathess, 1839. Possibly older.

85. Word. Mr. Word of Mississippi will, we think, get a seat in Congress to which he has been fairly elected. The House is a talking body, but Mississippi will probably be able to thrust in a Word edgewise (p. 37). 
86. Worth. Gen. Worth is a New Yorker, and no New York paper expresses a doubt of his Whiggism. There may be a good deal of merit among the Democratic officers and soldiers of the army, but there is no Worth among them - - no general Worth, and, so far as we know, no private Worth (p. 163).

87. Wright-Bright. The quarrel between those two prominent Democrats, Governor Wright and Senator Bright of Indiana, still continues. A locofoco paper, friendly to both, says there is not much difference between them. There is some though. Bright is sometimes right, but Wright is never bright (p. 200).

88. Young. A writer in the Literary Messenger asks if there is no way to remain young? Certainly there is. She can go to Utah and marry Brigham (p. 295).

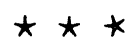

Menhaden, a well-known commercial fish is seldom known by its real name. Instead it is called alewife, bonyfish, bugfish, bughead, chebog, fatback, greentail, mossbunker, whitefish and other local names.

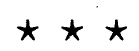

Money. The name of the town Money in Mississippi is somewhat misleading. There is not even a bank in the town. In fact, it has nothing to do with currency but was named after U. S. Senator H. D. Money. 